RESEARCH ARTICLE

\title{
Constraints Perceived and Suggestions Offered by the members of Tribal Farmer Producer Groups (FPGs)
}

\author{
Srikar Katiki ${ }^{* 1}$, Asokhan $\mathbf{M}^{1}$, Karthikeyan $\mathbf{C}^{1}$ and Patil S G ${ }^{2}$ \\ ${ }^{1}$ Department of Agricultural Extension and Rural Sociology, Tamil Nadu Agricultural University, Coimbatore-641 003 \\ ${ }^{2}$ Department of Physical Sciences and Information Technology, Tamil Nadu Agricultural University, Coimbatore-641 003
}

\begin{abstract}
Farmer Producer Groups (FPGs) have emerged as a possible solution to many of the problems faced by the Indian agriculture sector. The plight of small and marginal tribal farmers is aggravated by the weak marketing system: lack of quality input and technical services. The situation can be improved through collectivization when grouped and trained effectively, farmers can achieve enormous growth goals, finally making the group selfreliant and self-sufficient. The study focused on identifying the constraints faced by members of FPGs and possible suggestions for the tribal farmers of Seethampeta block of Srikakulam district, Andhra Pradesh. The study included 145 members, selected through a multi-stage proportionate random sampling method from three villages with the highest number of FPGs and members. Data collection was done through personal interview method and the respondents were provided with open-ended questions for listing out the constraints faced by them and suggestions for improving the effectiveness of FPGs. The constraints listed were then grouped into economic, marketing, organizational, technical and socio-cultural constraints. The collected data were analyzed using frequency and percentage. The ranking was given based on the percentage for easy identification of the major and minor constraints faced by the tribal farmers of FPGs under study.
\end{abstract}

Keywords: Constraints; Farmer Producer Groups (FPGs); Suggestions; Tribal farmers.

\section{INTRODUCTION}

The need of the hour in the present era of globalization and trade liberalization is to reshape the mere producer of agricultural products into the producer and seller of the product by developing rural entrepreneurship through the concept of collectivization or group initiation through the local level organisation. A viable technology transfer mechanism is required to promote sustainability in food production and marketing for income generation.

To double the farmers' income, a collective approach with enhanced technology, practices, processing, marketing, and entrepreneurial development is required. Small and marginal farmers are the primary contributors to agricultural production in India and thus, 85.00 per cent of farmers possess less than or about two hectares (Sharma et al., 2011) of land. Collective strategy can be used to overcome the challenges faced by small and marginal farmers and to empower them by providing access to quality input, technical assistance, and a platform to directly market their agricultural products, among other things. The farmers' producer organizations and producer companies are much beneficial to improve the value chain of agricultural produce and thereby proved to be, getting good prices for their produce (Sawairam, 2014).

Farmers' organisations were recognized as valuable tools for mobilizing farmers and were formed to recognize the value of group action. The creation of countervailing power, access to capital markets on favorable terms, risk management, and income improvements are other major reasons for establishing farmers' organizations (Datta, 2004). Farmer organizations can increase the access of small producers to new technology, market information and business services in rural areas that contribute to productivity, growth, intensification and commercialization of smallholder agriculture, thereby increasing their incomes (Shiferaw et al., 2016). Gill and Prasad (2009) stated that whatsoever information reaches to small farmers is often not backed by scientifically proven results in different farming situations prevailing in Indian sub-continent. 
India has the largest tribal population in the world of 10.43 crores, according to the 2011 census, Andhra Pradesh state constitutes 8.6 per cent of the total tribal population. Difficulty in accessing credit, unable to benefit from the use of farm machinery due to small land holdings, poor knowledge about markets are some of the major problems faced by the tribal farmers. Tribal FPGs will play a unique role in improving the economic status of tribal people through which they can access credit, market facilities and value-added forest produce (Mathuabirami and Kalaivani, 2020). However, in spite of the widespread evolution of farmer organizations, their success across the world had shown mixed results (Chirwa et al., 2005). The main objective of the study is to identify the constraints in the functioning of tribal FPGs and to sort out some suggestions for the effective functioning of FPGs. The success of these farmer producer organizations is very much dependent on the commitment of the members. Integrity, quality leadership and the suitable market environment are the most critical factors for the successful growth of such organizations (Kathiravan et al., 2017).

\section{MATERIAL AND METHODS}

The research was purposively carried out in the Seethampeta block of Srikakulam district in Andhra Pradesh. The selected block has the highest number of FPGs, i.e., 243 in 61 villages with 2875 FPG members. A sample size of 145 was selected proportionately from the top three villages with the highest number of FPGs i.e., Kusumi, Keesaraijodu and Somagandi, employing a multistage proportionate random sampling method. An ex post facto research design was adopted for the study. The data collection was done using a pretested interview schedule. The respondents were provided with open-ended questions for listing out the constraints faced by them in FPGs and suggestions for increasing the effectiveness of FPGs. Then the listed constraints were grouped into categories like economic, marketing, organizational, technical and socio-cultural constraints. Frequency and percentage were used for analyzing the collected data and ranks were given based on the percentage to facilitate the identification of major and minor constraints faced by the tribal farmers of FPGs.

\section{RESULTS AND DISCUSSION}

\section{Constraints faced by the members of tribal FPGs}

Constraints are omnipresent because they are the most important item a farmer encounters during the production and marketing. The constraints faced by the members of tribal FPGs are listed out during the survey and are grouped into different categories based on their similarities. The distribution of respondents based on the constraints faced by them in the tribal FPGs are listed in Table. 01.

\section{A.Economic constraints}

The FPGs are not provided with sufficient credit and therefore, they are not financially strong enough to deliver dynamic products and services to maintain their market share. From Table. 01., it is understood that 86 per cent of farmers reported that insufficient credit had been the significant constraint followed by 76 per cent of limited financial resources as they are vulnerable tribal communities. The procedure for availing loans was little complicated as all the farmers were not literate and 59 per cent of the respondents consider it as a constraint. Socioeconomic problems like poverty, low literacy rate, lack of access to resources etc. are the major weaknesses of the Farmers Organizations (Chirwa et al. 2005; Jere 2005).

\section{B.Marketing constraints}

The profit margins for the farmers are more than 60 per cent, but due to the low quantity of the transaction, farmers are not benefited (Pujara, 2016). The members of FPGs in tribal areas lack proper knowledge on demand and pricing and had less bargaining power. Nearly 88 per cent of the respondents admitted that they lack marketing skills and 72 per cent of respondents felt high transportation cost as one of the major constraints, followed by 63 per cent for gaps in supply chain management. Tribal farmers' inability to develop scale economies, low bargaining power were due to low amounts of marketable surplus, scarcity of money, lack of market access, lack of knowledge and information, market flaws, and poor infrastructure and communications (Barham and Chitemi, 2009).

\section{C.Organizational constraints}

Farmer producer groups should be organised in a more business-like manner. The organizational structure and rules are critical in shaping any form of collective action. They should maintain a regular dialogue with members and there should not be any bias between the members of the group. About 92 per cent of the respondents felt that inadequate staff at the grassroots level for guidance and 83 per cent of members reported that training was not given to all the members. Over the last two decades, structural adjustment programmes have resulted in a decrease in state-funded agricultural support, making it impossible for many farmers to receive sufficient training and local assistance(Markelova et al., 2007).

\section{D.Technical constraints}

For effective functioning of groups, well-trained, experienced and professional staff should be hired. 
They should be active enough to trace the new opportunities and make use of them for further improvement of farmers both individually and groups. A proper working environment and facilities should be provided for maximum use of provided resources. 74 per cent of the respondents reported that there was lack of proper infrastructure. Storage is usually expensive and spoils the freshness and quality of the produce. Sixty-six per cent of the respondents admitted that they were facing constraints due to a lack of post-harvest management facilities. The deregulation and the subsequent decline in state subsidies for production inputs such as water, electricity, fertilizer, and seeds created an economic environment of uncertain competition for many smallholders (Motiram and Vakulabharanam, 2007).

\section{E.Socio-cultural constraints}

There are many groups that do not follow the market trend and stick to the same old business principles as a part of social pressure or taboos as most common phenomena among indigenous tribes, which were reported as a constraint by 55 per cent of the respondents. Among the FPGs under study, about one fourth of respondents (26 per cent) felt that there was lack of communication and participation among members as the least constraint. Organizing tribal farmers into farmer producer groups is a herculean task due to their diverse sociocultural and political contexts.

Table. 01. Constraints faced by the members of tribal FPGs

\begin{tabular}{clccc}
\hline S. No. & \multicolumn{1}{c}{ Constraints } & Frequency (No.) & Percentage (\%) & Rank \\
\hline A. Economic constraints & & & \\
1. & Limited financial resources & 110 & 76 & V \\
2. & Complicated procedure for availing loans & 86 & 59 & XI \\
3. & Insufficient credit & 125 & 86 & III \\
4. & Inadequate income generation & 60 & 41 & XVII \\
5. & No assured buy back and price & 90 & 62 & X \\
\hline
\end{tabular}

B. Marketing constraints

\begin{tabular}{llccc} 
1. & Gaps in Supply Chain Management & 92 & 63 & IX \\
2. & Lack of market awareness & 70 & 48 & XIV \\
3. & High transportation cost & 104 & 72 & VII \\
4. & Exploitation by middlemen and traders & 47 & 32 & XXI \\
5. & Lack of marketing skills & 127 & 88 & II \\
\hline
\end{tabular}

C. Organizational constraints

$\begin{array}{clccc}\text { 1. } & \text { Lack of team spirit } & 56 & 39 & \text { XVIII } \\ \text { 2. } & \text { Ineffective linkage with financial institutions } & 84 & 58 & \text { XII } \\ \text { 3. } & \text { Inefficient monitoring } & 43 & 30 & \text { XXII } \\ \text { 4. } & \text { Trainings were not given to all the members } & 121 & 83 & \text { IV } \\ \text { 5. } & \text { Inadequate staff at grass root level } & 134 & 92 & \text { I }\end{array}$

D. Technical constraints

\begin{tabular}{lllll} 
1. & Untimely, costly and poor quality of inputs & 61 & 42 & XVI \\
2. & Lack of proper infrastructure & 107 & 74 & VI \\
3. & Inadequate technical guidance & 55 & 38 & XIX \\
4. & Lack of post-harvest management facilities & 96 & 66 & VIII \\
\hline
\end{tabular}

E. Socio-cultural constraints

\begin{tabular}{|c|c|c|c|c|}
\hline 1. & Social pressures and taboos & 80 & 55 & XIII \\
\hline 2. & Lack of conflict management skills & 52 & 36 & $X X$ \\
\hline 3. & $\begin{array}{l}\text { Lack of communication and participation } \\
\text { among members }\end{array}$ & 38 & 26 & XXIII \\
\hline 4. & Lack of decision making ability & 62 & 43 & $X V$ \\
\hline
\end{tabular}




\section{Suggestions}

The FPGs should be provided with proper and adequate financial assistance and timely diffusion of technical know-how knowledge. The members of the FPGs should be provided with input-oriented subsidies. Small-scale farmers can have easy access to market information, credit and input for their production, processing, and marketing activities by joining Farmer Based Organizations (Asante et al. 2011). The extremely successful collateral-free, Self-Help Group-bank linkage programme should be extended for FPGs, focusing on a case-by-case business analysis and cash flows rather than collateral. This would also aid in lowering the interest load on FPGs.

The linkage between the marketing institutions should be strengthened to reduce the gaps in supply chain management. The establishment of organized supply chain management can reduce the exploitation by middlemen and traders. Linkages with private sector companies, corporate markets, government institutes, and research and extension institutions will assist FPGs in being more dynamic and competitive. Effective monitoring mechanism is essential to reduce the wastage of resources, cost of the production and also for tracing the opportunities of income generation and marketing.

Understanding and cooperation between the members of the FPGs are key factors that contribute to effective functioning. The members should be encouraged to participate in group activities. Effective leadership can earn members' trust, inculcate ethics in the organisation, create linkages, influence the members towards quality production, and act within the boundaries of the legal framework will contribute to the overall success and sustainability of FPGs.

The transformation in information and communication technology (ICT) can be efficiently leveraged for the efficacy and success of FPGs. Mobile, internet, and other technologies are useful means of reaching out to all members, providing advice, and resolving production-related issues. Members of tribal FPGs can also be linked to buyers and customers via websites, mobile-based applications, or phone calls in marketing. ICT can even connect all FPGs in a virtual federation where members can communicate and learn from the successful FPGs experience.

\section{CONCLUSION}

Based on the findings of the study, the major constraint faced by the members of the FPGs was the lack of the adequate staff to provide guidance in group activities. To mitigate the issue, it is suggested to hire more experienced, trained and professional staff who can contribute to the improved functioning of FPGs. The study reveals that the respondents lack marketing skills due to which they are poor in availing the benefits of collectivization. Need-based training should be provided without any bias between the members of the group. The credit provided was insufficient and should be increased to improve the market share of the producers and transportation costs should be minimized. As the success of any organization or group depends on the commitment of the members, the participation of the members should be improved and they should be involved in the decision-making process. The constraints faced by the members of the FPGs and the suggestions offered should be taken into account which can help for better planning of future projects and activities.

\section{Ethics statement}

Specific permits were not required for the above field studies because no human or animal subjects were involved in this research.

\section{Consent for publication}

All the authors agreed to publish the content.

\section{Competing interests}

There was no conflict of interest in the publication of this content.

\section{Data availability}

All the data of this manuscript are included in the manuscript. No separate external data source is required. If anything is required from the manuscript, certainly, this will be extended by communicating with the corresponding author through corresponding official mail xxxxxxxxx.

\section{REFERENCES}

Asante B. O., Afari-Sefa, V. and D.B. Sarpong. 2011. Determinants of small scale farmer's decision to join farmer based organizations in Ghana. African J. of Agric. Research., 6(10): 2273-79.

Barham, J. and C. Chitemi. 2009, Collective action initiatives to improve marketing performance: lessons from farmer groups in Tanzania. Food Poiicy., 34:53 - 59.

Chirwa, E., Dorward, A., Kachule, R., Kumwenda, I., Kydd, J., Poole, N., Oulton,C. and M.Stockbridge. 2005 Farmer organisations for market access: principles for policy and practice. https:// assets.Publishing .service.gov. uk /media/ 57a08c60ed915d622c0012e1/R8275_040524_ PolicyBriefingPaper.pdf.

Datta, S. K. 2004, Co-operatives in agriculture: philosophical and theoretical foundations of co-operatives, in State of the Indian Farmer- A Millennium Study Government of India Ministry of Agriculture (Academic Foundation, New Delhi) 38- 67. 
Gill, M.S. and K. Prasad. 2009. Organic AgricultureConcept, Status and Strategies in Indian Perspective. Compendium on Advances in Organic Farming, Project Directorate for Farming System Research., ICAR, Modipuram., 1-7.

Jere, P. 2005. Inventory and SWOT Analysis of Farmer Organizations in the SADC Region A regional synthesis report on Strengths, Weaknesses, capacity needs and communication needs of FOs in the SADC. Submitted to Food, Agriculture and Natural Resources Policy Analysis Network (FANRPAN), Malawi. Available: http://www.fanrpan. org/documents/d00049/ Inventory_and_SWOT_ analysis.pdf.

Kathiravan, N., Senthilkumar, T. and N.K. Sudeep Kumar. 2017. Identification of Bottlenecks Perceived among the Farmer Producer Organizations to Augment its Role and Function. Int.J.Curr. Microbiol.App.Sci. 6(9): 216-219. doi: https://doi. org/10.20546/ijcmas.2017.609.029.

Markelova, H., Meinzen-Dick, R., Hellin, J. and S. Dohrn. 2009. Collective action for smallholder market access. Food Policy., 34(1): 1-7.
Mathuabirami, V. and S. Kalaivani. 2020. An Analytical Study on Relationship of Profile Characteristics with Effectiveness of Tribal FIGs in Tamil Nadu. Madras Agric.J., 107(4-6):216-219.

Motiram, S. and V.Vakulabharanam V. 2007. Corporate and cooperative solutions for the agrarian crisis in developing countries. Review of Radical Political Economics., 39: 360 - 367.

Pujara,M. 2016. Problems and Issues facing Farmers groups and cooperatives in Agriculture marketing. Agricultural Technology and Management Agency., 12 (1): 420.

Sawairam, P.2014. Case study on Farmer Producer Organization in Maharashtra in the era of globalization. IMRD's J. of Management and Research., 4(2): 1-11.

Sharma, J., Singh, P. and R. Padaria. 2011. Social Processes and People's Participation in Watershed Development. J. of Comm. Mobi. and Sus. Devlop., 6(2):168-173.

Shiferaw, B., Hellin, J. and G. Muricho. 2016. Market access and agricultural productivity growth in developing countries: Challenges and opportunities for producer organizations. Eco. Dmc., 1:103-124. 